\title{
Collaborating with Nature: The Pristine Habitats, in Ugep, Yakurr L.G.A., Nigeria
}

\author{
Peter Onen Oka*, Stanley Monkayuk Majuk \\ Department of Geography \& Environmental Science, University of Calabar, Calabar, Nigeria \\ Email: peteroonen@yahoo.com
}

Received 4 January 2016; accepted 14 February 2016; published 17 February 2016

Copyright $(\subseteq 2016$ by authors and Scientific Research Publishing Inc.

This work is licensed under the Creative Commons Attribution International License (CC BY). http://creativecommons.org/licenses/by/4.0/

(c) (i) Open Access

\section{Abstract}

Pristine habitats serve as ecological resource for educational services and the conservation of biodiversity. The need to maintain a balance between nature and development is very important. When pristine habitats face changes due to anthropogenic activities, species erosion sets in and this will eventually lead to extinction. This subtle move in most cases is unnoticed until the effects are established. The pristine habitats in Ugep are faced with this challenge. The Ugep Urban Landuse Master Plan and Ugep Orthophoto map [1] have been used to identify the pristine habitats and further calculate the total landmass to be approximately 855.38 hectares. Ten (10) pristine habitats were identified within the residential blocks along the drainage corridors of Loblo, Isayi, Mma Oden, Kiwei, Ewiden and Oganghwen. The pristine block at Njelokoko-2 has the highest landmass, 201.01 hectares, representing 23.50 percent while Njelokoko-1 has the least landmass, 18.99 (2.22 percent). The spatial turnover of the species composition shows a trend of direct proportion with the landmass size and anthropogenic activities in the pristine habitats. Tree species such as Albizia zygia and Artocarpus communis rarely occurred together with other tree species. Among the bird species, it was observed that Dendropes goerae, Milvus migrans, Pica pica, and Streptopelia senegalensis roost, breed and feed in pristine habitats with emergent trees while $\mathrm{Ha}$ locyno leucoephala, Halocyno malimbicus, Frasena clnernscens, Streptopelia semitorguata and Crimifer piscator are restricted to narrow corridors of pristine habitats along stream buffers. The nature that the pristine habitat portends and the species observed in such highly urbanized context as Ugep, are very important in conservation planning and meeting the urban challenges.

\section{Keywords}

Pristine Habitat, Ecological Integrity, Habitat Heterogeneity, Biodiversity, Ecological Footprint

\footnotetext{
${ }^{*}$ Corresponding author.
} 


\section{Introduction}

The importance of nature generally is as old as human existence and anthropogenic activities. Most residential areas are littered with pristine habitats that are used for social activities with little or no interest to probe further on the benefits of these habitats. Singapore nurtures its garden city image and currently has 2340 hectares of park and green areas and about 3000 hectares of nature reserves. Thus, Singapore's urban planning preserves greenery, watershed clean air. The Mahim National Park project highlights the importance of green spaces to clean up Mumbai and decrease pollution levels [2].

Pristine habitats in Ugep urban have served as garbage dump, with slums on one side and dilapidated buildings on the other side. Today these sites are serving as ecologically restored nature sites dotted with plant and animal species. In 1998, the Cross River State Government of Nigeria conceived and established the Ugep Urban Development Authority (UUDA) with additional responsibility of developing, managing, promoting and day-to-day sanitization of the pristine sites without necessarily destroying the initial vegetation. Apart from providing residents with a green and unpolluted environment, pristine habitats in Ugep serve as recreational and educational resource, offering instructions in ecology, biodiversity and nature conservation. Thus, the pristine habitats are designated as outdoor laboratory serving as home to both fauna and flora, and for the study of different habitats and ecological functions of various species. In the main time, visitors to the pristine sites range from children from local slums and villages, to naturalist from around the world.

Greater habitat heterogeneity connotes greater species diversity [3]. Although community level analyses of the effect of habitat heterogeneity on species are important, they do not reveal the mechanism through which heterogeneity affects diversity [3]. In contrast, habitat associations of particular species suggest a potential mechanism whereby diversity is affected by habitat heterogeneity. In a study on the variance in species composition, pristine habitats close to each other are quite similar in species composition than those apart under the same environmental condition [4]. This implies that change in habitat quality will more affect the mean and variance richness of plant and animal species than complete loss of habitat. The dynamics of compressing patches of the pristine habitats is increasingly seen as essential in understanding the persistence of association between wildlife and human activities.

As urban areas grow and develop, they rely on natural resources farther away to meet their production and consumption demands. In the process, their ecological footprint weighs heavier on natural environment [5]. The ecological footprint represents the land area necessary to sustain consumption and waste disposal of the population. This concept provides a measure of the impact that population has on nature.

Besides being located in the areas with non-renewable natural resources, most pristine habitats in Ugep are located in extensive watersheds with green areas, some having exotic species and concentrated high biodiversity. Considerable changes that are occurring in the pristine habitats because of both natural and anthropogenic transformation such as upstream developmental activities, urbanization and population pressure naturally have heavy toll on ecological integrity of pristine habitats. Pristine habitats are environmentally sensitive and fragile.

In recent times, the protection of the global environment has become of great concern. This is associated with the threat of environmental degradation following the activities of man in a bid to satisfy his needs. Land use and land cover change due to sprawl are current leading causes of biodiversity losses in pristine habitats within urban areas [6].

The Nigerian Environmental Study Team (NEST) revealed that the Nigerian environment is threatened by natural changes and human activities [7], which are mounting pressure on environmental resources. It was established that at a growth rate of 3.3 percent, the Nigerian population will double by the year 2013 leading to further negative consequences on the environment [8] [9]. With rapid urban growth in Nigeria, pristine habitats as prime reserved lands are already in danger.

Under the present intensive use of land, Ugep is in danger of mass species erosion in the pristine habitat within the metropolis. The little or scanty knowledge base of the biodiversity status of the pristine habitat may hamper policies toward their preservation. This is particularly in context of competing land uses arising from growth and flux of population and expanding socio-economic activities in urban areas. Without a spread of strong knowledge base of genetic and species importance of pristine habitats and what potential they hold for biodiversity conservation, feature effort to preserve it will be jeopardized.

\section{Objectives}

1) To identify the pristine habitats in the study area. 
2) To examine the biodiversity status of the pristine habitats in the study area.

\subsection{Significance and Scope}

This paper is an attempt to identify the pristine habitats in the study area. Furthermore, it will highlight the need for urban planners to focus attention on the restoration and rehabilitation of pristine habitats to generate new values from such spaces. Also, in the bid promote tourism and sustainable cultural heritage in the conservation of biodiversity, and contribute to planning, monitoring and evaluation of pristine habitats.

The scope of this study is limited to Ugep, Nigeria. The tree community was taken among species that were found within demarcated sample plots for the purpose of this paper. Trees associated with streets and roadside plantings, household yards and gardens were excluded from floral inventorying because it is artificial. Bird inventorying were taken among bird species that are in the wild and those using the air space but captive birds were excluded.

\subsection{Study Area}

Ugep lies between longitudes $08^{\circ} 03^{\prime} 40^{\prime \prime} \mathrm{E}$ and $08^{\circ} 05^{\prime} 44^{\prime \prime} \mathrm{E}$, and latitudes $05^{\circ} 47^{\prime} 30^{\prime \prime} \mathrm{N}$ and $05^{\circ} 48^{\prime} 33^{\prime \prime} \mathrm{N}$; occupying a total landmass of about $48 \mathrm{Km}^{2}$. The zone of saturation in the cretaceous rocks of the area is shallow and ground water is available from joints and fissures. The shale rocks of the group promote flash floods with the result that most of the streams that drain the areas dry up soon [10]. Ugep as a region have very low drainage density that accounts for the poor distribution of tree population in areas other than sub watersheds. The sub water sheds usually consist of primary vegetation that are pristine and habitats to wildlife. The hottest months of the year are February to April and the coldest month is August, having an average temperature of about $27^{\circ} \mathrm{C}$. There is a long wet season from April to July, interrupted by a short dry period in August and then another short wet season from September to October. Rainfall varies from $2500 \mathrm{~mm}$ to $3000 \mathrm{~mm}$ annually.

The study area is located in one of the world's richest biodiversity hot spot, the Lower Guinean Forest, separated from the rest of the Upper Guinean Forest by the Dahomey Gap [11]. The floral and faunal communities in the study area are ideal subjects to examine the biodiversity status in the ecology of an urban setting hence probing into the benefits of collaborating with nature, based on the premise that flora and fauna in Ugep covers a wide range of pristine environment (Figure 1). As population continues to increase, human activities affect vegetation as areas once known for luxuriant vegetation are being fragmented leaving behind small patches of pristine habitats. The pristine habitats in Ugep have shown trends of encroachment along the drainage corridors of Loblo, Isayi, Mma Oden, Kiwei, Ewiden and Oganaghween. Allowing further encroachment implies that soon all the pristine habitats will give way to other uses with detrimental effects on biodiversity. This paper will examine the benefits of collaborating with nature using pristine habitats in an environment.

\section{Methodology}

Obtaining reliable and accurate information on the number and spatial distribution of the pristine habitat constitute a crucial step to understanding of biodiversity status of the study area. The Ugep Master Plan, Ugep Orthophoto Map [1] and ground truthing were used for this purpose. Tree and bird species in the identified pristine habitats were examined and the number in the demarcated plots documented based on field observation. The choice of bird species is because birds have been observed to be good environmental indicators and are useful in detecting unexpected changes in an environment [12].

Only site with pristine characteristic such as luxuriant trees with minimal or no interference of anthropogenic activities was used to facilitate investigation, hence, ten (10) pristine habitats were chosen (Table $1 \&$ Figure 1 ). To maximize data collection, a $100 \times 100$ square meter quadrate was used on each sample plot selected. The limits of the pristine habitats were first outlined on a tracing paper from the orthophoto map of the study area, clipped on a graph paper and the computation of the approximate size of each identified pristine habitat carried out. The Time-Species Count (TSC) method was further adopted in recording identified bird species, in order to avoid duplication of count at a given time.

\section{Result and Discussion of Finding}

The most fundamental pristine habitats in this study area have hierarchical structure that follows networks formed 


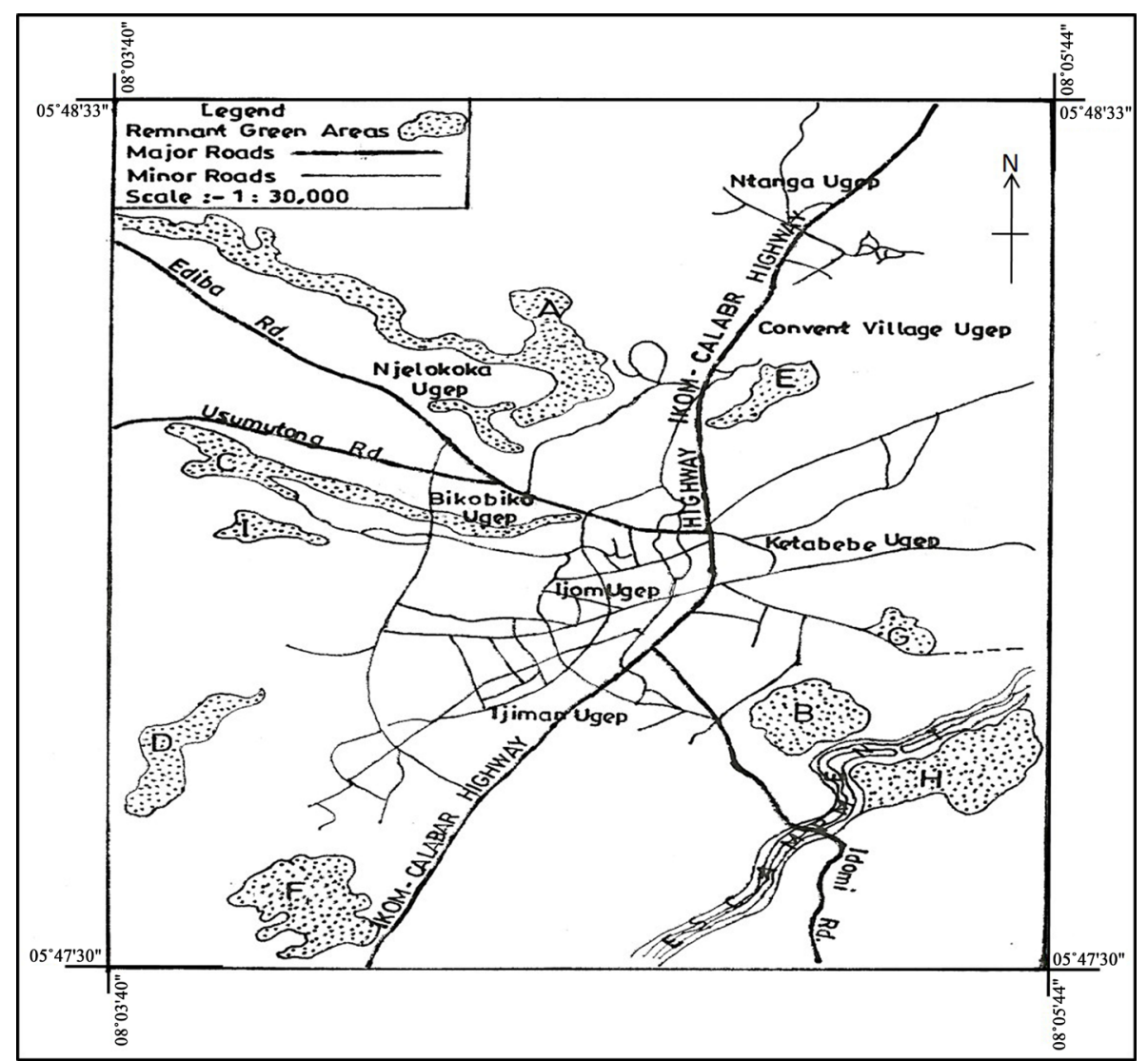

Source: authors' field research, 2015.

Figure 1. Pristine habitats (remnant green areas) in Ugep metropolis, Nigeria.

Table 1. Location and sizes of pristine habitats in the study area.

\begin{tabular}{|c|c|c|c|c|}
\hline Pristine Habitat & $\begin{array}{l}\text { Habitat Identity on Study Map } \\
\text { (Figure 1) }\end{array}$ & $\begin{array}{l}\text { Geographic } \\
\text { Coordinates }\end{array}$ & Size (Hectare) & Percentage \\
\hline Njelokoko-1 & A & $\begin{array}{l}08^{\circ} 04^{\prime} 40 " \mathrm{E} \\
05^{\circ} 48^{\prime} 12 " \mathrm{~N}\end{array}$ & 201.01 & 23.50 \\
\hline Ijiman-1 & B & $\begin{array}{l}08^{\circ} 05^{\prime} 16 " \mathrm{E} \\
05^{\circ} 47^{\prime} 48^{\prime \prime} \mathrm{N}\end{array}$ & 67.66 & 7.91 \\
\hline Bikobiko-1 & $\mathrm{C}$ & $\begin{array}{l}08^{\circ} 03^{\prime} 52^{\prime \prime} \mathrm{E} \\
05^{\circ} 48^{\prime} 06^{\prime \prime N}\end{array}$ & 111.63 & 13.05 \\
\hline Ijiman-2 & $\mathrm{D}$ & $\begin{array}{l}08^{\circ} 03^{\prime} 46 " \mathrm{E} \\
05^{\circ} 47^{\prime} 45^{\prime \prime N}\end{array}$ & 83.23 & 9.73 \\
\hline Ntankpo & E & $\begin{array}{l}08^{\circ} 05^{\prime} 09 " \mathrm{E} \\
05^{\circ} 48^{\prime} 10^{\prime \prime} \mathrm{N}\end{array}$ & 47.39 & 5.54 \\
\hline Ijiman-3 & $\mathrm{F}$ & $\begin{array}{l}08^{\circ} 04^{\prime} 04^{\prime \prime} \mathrm{E} \\
05^{\circ} 47^{\prime} 36^{\prime \prime} \mathrm{N}\end{array}$ & 112.31 & 13.13 \\
\hline Ketabebe & G & $\begin{array}{l}08^{\circ} 05^{\prime} 26^{\prime \prime} \mathrm{E} \\
05^{\circ} 48^{\prime} 54^{\prime \prime} \mathrm{N}\end{array}$ & 30.45 & 3.56 \\
\hline Ijiman—4 & $\mathrm{H}$ & $\begin{array}{l}08^{\circ} 05^{\prime} 30^{\prime \prime} \mathrm{E} \\
05^{\circ} 47^{\prime} 44^{\prime \prime N}\end{array}$ & 154.31 & 18.04 \\
\hline Bikobiko-2 & I & $\begin{array}{l}08^{\circ} 03^{\prime} 58^{\prime \prime} \mathrm{E} \\
05^{\circ} 48^{\prime} 02^{\prime \prime N}\end{array}$ & 28.40 & 3.32 \\
\hline Njelokoko—2 & $\mathrm{J}$ & $\begin{array}{l}08^{\circ} 04^{\prime} 30 " \mathrm{E} \\
05^{\circ} 48^{\prime} 08^{\prime \prime} \mathrm{N}\end{array}$ & 18.99 & 2.22 \\
\hline
\end{tabular}

Source: authors' field research, 2015. 
by stream systems. The pristine habitats at Bikobiko and Njelokoko are located along stream buffers while the pristine habitats at Ijiman and Ketabebe are located in the sites of ancient shrines (Figure 1).

As shown in Table 1, the pristine habitats in Bikobiko and Njelokoko occupy 360.03 hectares representing 42.09 percent while the remaining 495.35 hectares representing 57.91 percent is distributed among Ntankpo, Ijiman and Ketabebe pristine habitats. Disjointed pristine habitats are created by road crossings, wetland eradication, farmland clearing, urban development and rugged terrain.

Table 2 and Table 3 highlight the spatial turnover in the tree and bird species composition respectively in the study area. The survey revealed that the tree species richness is higher Njelokoko-1, recording eleven (11) bird species representing 36.67 percent while the lowest number was observed at Ijiman-1 and Ntankpo with four (4) bird species each representing 13.33 percent. The two (2) most common tree species, Gmelina arbora and Elaeis guineasis, in all the sites observed are exotic species. Seventeen (17) tree species were recorded as remnants of ancient forest while 27 bird species distributed among 18 families were observed in the study area. Njelokoko has the highest number of bird species (15) representing 57.65 percent.

The extent of the natural area varied significantly across the urban gradient from city center to the exurban; vestiges of natural vegetation remain primarily along stream buffer, village squares and shrines. The most evident problem in the study area is that pristine habitats apart from being unevenly distributed, careful attention is not given to the ecological value they possess. The current spatial concept of the pristine habitats in the study area was observed to consist of two zones: the inner and outer pristine habitats. The inner pristine habitat (Njelokoko, Ntankpo and Bikobiko) are located at a transition between the city center and the new layout at the exurban. While the outer pristine habitats on the other hand, are located at the transition of the exurban. The expansion of built-up areas have not only reduced the size and influence the spatial spread of the pristine habitats, but has destroyed the habitats of tree and bird species, hence, giving rise to few surviving species to share available space. Consequently, this has created a horizontal heterogeneity, which is manifested by the disconti-

Table 2. List of tree species observed in the exurban and urban green areas in Ugep.

\begin{tabular}{|c|c|c|c|c|c|c|c|c|c|c|c|}
\hline \multirow{2}{*}{ SPECIES } & \multicolumn{11}{|c|}{ Exurban and Urban Green Area } \\
\hline & A & B & $\mathrm{C}$ & $\mathrm{D}$ & E & $\mathrm{F}$ & G & $\mathrm{H}$ & I & $\mathrm{J}$ & Total \\
\hline Alizia zygia (mimosoideae) & 0 & 0 & 0 & 0 & 0 & 0 & 0 & 0 & 0 & 1 & 1 \\
\hline Albizia gumifera (Mimosoideae) & 0 & & 1 & 0 & 0 & 0 & 1 & 0 & 0 & 0 & 2 \\
\hline Bombax buonopozese & 1 & 1 & 0 & 0 & 0 & 1 & 0 & 0 & 1 & 0 & 4 \\
\hline Terminalian ivorensis (combietaceae) & 0 & 0 & 0 & 0 & 0 & 0 & 0 & 0 & 0 & 1 & 1 \\
\hline Gmelina arborea (Verbeacease) & 1 & 1 & 1 & 1 & 1 & 1 & 1 & 1 & 1 & 1 & 10 \\
\hline Tectona grandis (Verbeacease) & 1 & 0 & 0 & 1 & 1 & 1 & 0 & 1 & 1 & 0 & 6 \\
\hline Magnifera indicia (Chryobalance) & 0 & 0 & 0 & 0 & 0 & 1 & 1 & 1 & 1 & 0 & 4 \\
\hline Chlorophora excelse (Moraceae) & 1 & 1 & & 1 & 0 & 0 & 0 & 1 & 0 & 0 & 4 \\
\hline Terminalia guinesis (Ulmaceae) & 0 & 0 & 0 & 0 & 0 & 0 & 0 & 1 & 0 & 0 & 1 \\
\hline Combretum hispidum (Combretaceae) & 0 & 0 & 1 & 0 & 0 & 0 & 0 & 0 & 0 & 0 & 1 \\
\hline Terminalia superb (Combretaceae) & 0 & 0 & 0 & 0 & 1 & 0 & 0 & 1 & 0 & 0 & 2 \\
\hline Combretodendron macrocarpum (Lecythidaceae) & 1 & 0 & 0 & 1 & 0 & 0 & 0 & 0 & 0 & 0 & 2 \\
\hline Artocarpus commumis (Maraceae) & 1 & 0 & 1 & 0 & 0 & 0 & 1 & 0 & 0 & 0 & 3 \\
\hline Elaeis guineensis (Aracaceae) & 1 & 1 & 1 & 1 & 1 & 1 & 1 & 1 & 1 & 1 & 10 \\
\hline Steculia oblonga (Streculiacea) & 1 & 0 & 0 & 0 & 0 & 1 & 0 & 1 & 0 & 0 & 3 \\
\hline Irringia gabonensis (Irrengiacease) & 1 & 0 & 0 & 0 & 0 & 0 & 0 & 1 & 0 & 0 & 2 \\
\hline Disthernonan thus spp. (Leginminoseae) & 0 & 0 & 0 & 0 & 0 & 0 & 0 & 0 & 0 & 1 & 1 \\
\hline Amphymas pterocarpoides & 1 & 0 & 0 & 0 & 0 & 0 & 0 & 0 & 0 & 0 & 1 \\
\hline Total number of species in sample plots & 11 & 4 & 5 & 5 & 4 & 6 & 5 & 9 & 5 & 5 & \\
\hline Total number of tree species & & & & & & 17 & & & & & \\
\hline Total number of families & & & & & & 12 & & & & & \\
\hline
\end{tabular}

Source: authors’ field research, 2015. 
Table 3. List of bird species observed in the exurban and urban green areas in Ugep.

\begin{tabular}{|c|c|c|c|c|c|c|c|c|c|c|c|}
\hline \multirow{2}{*}{ SPECIES } & \multicolumn{11}{|c|}{ Exurban and Urban Green Area } \\
\hline & A & B & $\mathrm{C}$ & $\mathrm{D}$ & $\mathrm{E}$ & $\mathrm{F}$ & G & $\mathrm{H}$ & I & $\mathrm{J}$ & Total \\
\hline Grey-headed kingfisher (Akedinidae) & 1 & 0 & 0 & 1 & 0 & 1 & 0 & 0 & 0 & 0 & 3 \\
\hline Blue-breasted kingfisher (Akedinidae) & 1 & & 1 & 1 & 0 & 1 & 0 & 0 & 1 & 1 & 6 \\
\hline Grey-woodpeaker (Picidae) & 0 & 0 & 0 & 1 & 0 & 0 & 0 & 1 & 1 & 1 & 4 \\
\hline Forest Robin (Turdidae) & 0 & 0 & 0 & 1 & 0 & 0 & 1 & 1 & 0 & 0 & 3 \\
\hline Forest-fly catcher (Muscipidae) & 1 & 0 & 0 & 0 & 0 & 1 & 0 & 0 & 0 & 1 & 3 \\
\hline Sunbird (Rubescens) & 0 & 1 & 0 & 0 & 0 & 0 & 0 & 1 & 1 & 0 & 3 \\
\hline Ruff-throated sunbird (Nectariaridae) & 1 & 1 & 1 & 0 & 0 & 0 & 0 & 0 & 0 & 0 & 3 \\
\hline Pied crow (Corvidae) & 0 & 1 & 1 & 0 & 0 & 0 & 0 & 1 & & 1 & 4 \\
\hline Spectached weaver (Ploceidae) & 1 & 0 & 1 & 0 & 1 & 0 & 1 & 0 & 0 & 1 & 5 \\
\hline Village weaver (Ploceidae) & 1 & 0 & 1 & 0 & 0 & 0 & 1 & 0 & 0 & 0 & 3 \\
\hline Canary (Fringillidae) & 0 & 0 & 0 & 0 & 1 & 1 & 0 & 1 & 0 & 0 & 3 \\
\hline Waxbill (Estrillididae) & 0 & 1 & 0 & 0 & 0 & 1 & 0 & 1 & 0 & 0 & 3 \\
\hline Cattle egret (Ardeidae) & 1 & 1 & 0 & 0 & 0 & 0 & 0 & 1 & 1 & 0 & 4 \\
\hline Heron (Aredidae) & 1 & 1 & 0 & 0 & 1 & 0 & 0 & 0 & 0 & 0 & 3 \\
\hline Black kite (Acciptridae) & 1 & 1 & 0 & 0 & 1 & 0 & 0 & 0 & 0 & 0 & 3 \\
\hline Palm-nut vulture (Pyconotidae) & 1 & 0 & 1 & 0 & 1 & 1 & 1 & 0 & 0 & 0 & 5 \\
\hline Turkey vulture (Carthartidae) & 0 & 0 & 0 & 0 & 0 & 0 & 0 & 1 & 1 & 0 & 2 \\
\hline African cuckoodhalrk (Accipitridae) & 0 & 1 & 1 & 1 & 0 & 1 & 1 & 0 & 0 & 0 & 5 \\
\hline Red-eyed dove (Columbidae) & 1 & 0 & 1 & 0 & 0 & 1 & 0 & 0 & 0 & 0 & 3 \\
\hline Laughing dove (Columbidae) & 1 & 1 & 0 & 0 & 0 & 1 & 0 & 1 & 1 & 1 & 6 \\
\hline Spotted eagle owl (Straigidae) & 1 & 0 & 1 & 0 & 0 & 0 & 0 & 1 & 0 & 0 & 3 \\
\hline Grey plantatin-eater (Musophaigidae) & 1 & 0 & 0 & 0 & 1 & 1 & 0 & 1 & 0 & 1 & 5 \\
\hline Sand martin (Hirundinidae) & 1 & 1 & 1 & 1 & 0 & 1 & 1 & 1 & 1 & 0 & 8 \\
\hline Robin-chat (Turdiae) & 0 & 1 & 0 & 0 & 0 & 0 & 1 & 0 & 0 & 0 & 2 \\
\hline Nightjar (Caprimulgidae) & 0 & 0 & 0 & 0 & 1 & 0 & 0 & 1 & 0 & 0 & 2 \\
\hline Typical (African palm swift). (Apodidae) & 0 & 0 & 0 & 1 & 0 & 1 & 1 & 0 & 0 & 0 & 3 \\
\hline Crested swift (Hemipronidae) & 0 & 0 & 0 & 0 & 1 & 0 & 0 & 0 & 0 & 1 & 2 \\
\hline Total number of species in sample plots & 15 & 10 & 9 & 8 & 8 & 12 & 8 & 13 & 8 & 8 & \\
\hline Total number bird species & & & & & & 28 & & & & & \\
\hline Total number of families & & & & & & 22 & & & & & \\
\hline
\end{tabular}

Source: authors' field research, 2015.

nuity of emergent tree species at sites located at stream buffers. Tree species such as Gmelina arbora and Elaeis guineasis, Berlivea confuse and, Terminelia superba were frequently seen in the same habitat. Albizia zygia and Artocarpus communis rarely occurred together with other tree species.

Bird species such as Haloyno leucoephala, Halocyno malimbicus, Frasena clnernscens, Streptopelia semitoguata and Crimifer piscator are restricted to narrow corridors of pristine habitats along stream buffers. Dendropces goertae, Milvus migrans, Pica pica and Streptopelia senegalensis were observed in pristine habitats with emergent tree species at Ijiman and Ketabebe.

\section{Conclusion}

The main trust of this paper is to investigate the biodiversity status of pristine habitats in Ugep, Nigeria. While linking pattern of biodiversity changes to relation in land use, there is evidence consistent with the idea that land 
use can modify species richness and hence biodiversity. Despite obvious constrains on ecological function, pristine habitats in Ugep provide important insights into the collaboration with nature through biodiversity conservation. The stream buffers located within pristine habitats in the study area as well as the kind of nature that it portends in such highly urbanized context are very important in conservation planning. Local conservation actions like the development of pristine habitats are critical for addressing the biodiversity crises in the midst of anthropogenic activities. This paper has highlighted the collaboration between pristine sites and urban biodiversity with man at the center of activities. Developments centered on pristine habitats should be reduced to the lowest ebb if not completely stopped. Such action will help to promote scientific research and tourism through bird watch activities.

\section{References}

[1] Ministry of Lands and Survey Headquarters (2003) Ugep Orthophoto Map. Ministry of Lands and Survey Headquarters, Calabar.

[2] Pye-Smith, C. (2001) Building Green Islands in Bombay. People \& the Planet. http://www.peopleandplanet.net/doc.php?id=1040

[3] Cramer, M.J. (1998) The Effects of Spatial and Temporal Heterogeneity on Rodent Diversity in a Semi-Arid Environment. Unpublished M.Sc. Thesis, Texas Technology University, Lubbock.

[4] Esspee, O. (2012) Threat Factors among Birds in Nigeria. Love Press, Enugu, 427 p.

[5] Chambers, N., Simmons, C. and Wackernagel, M. (2001) Sharing Nature’s Interest: Ecological Footprints an Indicator of Sustainability. Earthscan Publication, London, 208 p.

[6] Oka, O.P. (2009) The Biodiversity Status of Green Areas in Ugep, CRS, Nigeria. Unpublished M.Sc. Thesis, Department of Geography and Environmental Science, University of Calabar, Calabar.

[7] Olofin, E.A. (2000) Geography and Environmental Monitoring for Effective Resource Management. The Nigerian Geographical Journal, 3-4, 1-14.

[8] Mamman, A.B. (1996) Environmental Impacts of Urbanization and Sustainable Development. In: Daura, M.M., Ed., Issues in Environmental Monitoring in Nigeria, UNIMAID Press, Maiduguri, 45-56.

[9] National Population Commission (1991) Nigeria Census 1991. National Population Commission, Lagos,

[10] Ofomata G.E., Ed. (1975) Nigeria in Maps: Eastern States. Ethiope Publishing House, Benin City.

[11] Poorter, L., Bongers, F., Kouame, F.N. and Harthorme, W.D. (2004) Biodiversity of West African Forests: An Ecological atlas of Woody Plant Species. CABI Publishing, Singapore, $521 \mathrm{p}$. http://dx.doi.org/10.1079/9780851997346.0000

[12] Morrison, M.L. (1986) Bird Population as Indicators of Environmental Change. Current Ornithologist, 3, 429-451. http://dx.doi.org/10.1007/978-1-4615-6784-4 10 